\title{
Innovation and Establishment of Applied Undergraduate Training Mode
}

\author{
Bo Wu, Yong Zhu \\ School of Economics \& Management Chongqing Normal University, Chongqing 40133 China
}

Keywords: Applied undergraduate; training mode; innovation; establishment.

\begin{abstract}
With the development of Chinese social economy and readjustment of industrial structure, the demand for talents shows the characteristic of diversity. In order to satisfy the needs of social development for talents, most universities put emphasis on applied undergraduate training gradually. This paper analyzed and researched the innovation and establishment of applied undergraduate training mode.
\end{abstract}

\section{Introduction}

Chinese higher education has entered into the popularized stage through several decades of development. According to statistics, there are 1219 universities in China by 2015, including 796 public universities (395 universities, 401 undergraduate colleges), 141 private universities, 275 independent colleges; 7 Sino-foreign cooperative universities. The increase of undergraduate universities provides endless power for the improvement of talents training quality. However, from the viewing of the current station of talents training, the number of applied undergraduates is less and with low quality. The main reason of this situation is the unscientific training mode. Therefore, the innovation and establishment of applied undergraduate training mode must be strengthened.

\section{Concept Distinction of Applied Undergraduate Training Mode}

\subsection{Applied Undergraduate}

Applied undergraduate and academic undergraduate are two correspondent concepts. Academic undergraduates refer to talents who have great achievements on professional knowledge, while applied undergraduates refer to talents who have good practical ability and professional operation competence. There are obvious differences between the training methods of the two types of undergraduates. Here are the details:

First, in knowledge structure, the applied undergraduates do not attach great importance to the integrity and systemic of subject knowledge, but focus more on the improvement of professional ability and overall quality, requiring academic knowledge to serve the professional-oriented practice. Academic theory only needs to be learnt modestly, and student management production capacity and service production capacity training will be paid more attention to, focusing on improving students' professional adaptability, which can lay a solid foundation future. While academic undergraduates pay more attention to the promotion of professional knowledge, and practical ability training is relatively weak.

Second, in quality structure, academic undergraduates generally pay more attention to the improvement of subject knowledge accomplishment, while applied undergraduates focus more on improving professional quality, including professional ethics, professional responsibility, physical fitness, vocational skills, etc.

Third, in ability training, applied undergraduate emphasis more on the ability of adapting to the society, including employability, practical ability, innovative and entrepreneurial ability, interpersonal and communication skills. While academic undergraduate emphasis more on the richness knowledge, and their learning ability.

In short, the applied undergraduate refers to talent who is able to skillfully use their own knowledge. The training of vocational skills and improvement of ability structure are more important when training such talents, which will let them have the potential of lifelong learning and continuous improvement. 


\subsection{Talents Training Mode}

In "People's Republic of China National Economic and Social Development" Ninth Five-Year Plan and the 2010 vision outline, the "talent training model" concept was put forward first time. The document clearly pointed out to change the existing talent training model from examination-oriented education to comprehensive quality education. Since the introduction of the document, "talent training mode" has been widely used in Chinese education reform gradually. In 1998, Zhou Yuanqing, Vice Minister of Education of China, made a clearer definition of the concept of "Talent Training Mode". He pointed out: "Talent training mode essentially refers to the main goal of talent training, training specifications and the basic training methods." Then the relevant scholars explained "talent training model" in "Training Mode Theory": Talent training model refers to the basic form of talent training activities, which covers the methods of talent training, training methods, training process and training objectives. Based on views mentioned-above, talent training mode can be summarized as follows: guided by specific educational concepts and educational theories, according to the training objectives set by the education department and the talent training specifications, talent training mode through systematic teaching content, course organization and teaching evaluation to achieve the goal of personnel training.

\section{Main Problems in Chinese Applied Undergraduate Training Mode}

\subsection{Weak Practice Teaching}

For the training of applied undergraduate students, the practice teaching has always been relatively weak. Combination of production, research and other aspects is not close enough and implement situation is not very good. Specifically, in practice teaching there are mainly following Question: First, scientific assessment system isn't established, eventually leading to low teaching effectiveness. Second, in experimental design course, comprehensive experiments and independent design experiments are rarely involved, which led to the practical ability of students and practical potential cannot be well played. Third, the curriculum design is too single and comprehensive training courses accounted for less than purely theoretical courses. These problems reflect that the practice teaching in universities does not have the effective connection with the society, which leads students to master comprehensive theoretical knowledge, but do not know how to apply them. At the same time, the innovation consciousness is weak.

\subsection{Poor Applicability of Curriculum Teaching System}

\subsubsection{Teaching Contents and Curriculum System Separating Social Reality}

The development of modern society is changing rapidly, which also puts forward higher requirements for the development of education in China. In the process of actual teaching, the teaching content and curriculum system of colleges and universities must be compatible with the development of social economy and science and technology. However, according to the current status, most colleges and universities have not done this. There are two main problems: the first is the unscientific teaching materials, which didn't update according to time changing. Most of the colleges and universities are still using traditional teaching materials that tend to focus on theoretical knowledge, and lack of real cases in life, and most of the content of textbooks are relatively old, therefore, these materials are really unhelpful for undergraduate training. The second is curriculum setting is deviation from applied talent training, still in accordance with the requirements of training academic personnel. The proportion of subject courses and public classes is very large, but industry-related professional courses only few. It is obvious that this is not conducive to the promotion of students' practice ability. 3.2.2 Teaching Methods and Teaching Link Arrangement don't meet the Requirements of Applied Talent Training

Teaching methods have a very critical impact on the quality of teaching. From the current situation, when training applied talents there exists unreasonable teaching methods in many universities, for example, classroom teaching follows the traditional mode, rarely using case discussion, project method, research and other teaching modes. The application ability of students is also difficult to be 
trained in the classroom. In the teaching part, many arrangements are unreasonable which means only emphasizing on theoretical teaching rather than teaching practice. Obviously, this is deviates from applied undergraduate training objectives.

\subsection{Professional Settings without Characteristics}

Professional setting is a prominent problem of applied undergraduate training model in Chinese universities. The problem mainly shows in the following two aspects: first, in the professional settings process, most colleges and universities do not attach importance to market research, and just blindly pursue popular majors or emerging ones, which is inherently harmful and useless, because too many popular majors or new majors will greatly distract construction strength of the original majors, leading to the school's professional characteristics gradually buried. Second, because of lack of practical experience and subject foundation, the effect of new majors will be very weak, most of the new majors' theoretical researches are not deep enough, and the teacher staff is also very weak.

\subsection{Talent Training Specification and Objectives without Specificity}

The confirmation of talent training specifications and objectives is the premise to carry out applied talent training. Only making scientific personnel training specifications and objectives, can we cultivate good applied undergraduate. However, according to the current situation, many schools have not made a clear applied talents training specifications and objectives, and there are few related scholars do researches in this area. Some scholars put forward specific objectives of applied talents training, but they only put the "application" requirements of higher vocational colleges and universities together. In essence, it does not have the feasibility. Some scholars have suggested that the cultivation of applied talents should be promoted and supplemented with theoretical teaching, and should not only emphasize one side and neglect another aspect. This idea is relatively ideal. However, due to the constraints of objective conditions, including school time, class arrangements, etc., in practice it is not feasible.

\section{Innovation and Construction of Applied Undergraduate Training Mode}

\subsection{Feasibility Analysis}

The applied undergraduate training mode students embodies the basic characteristics of applied undergraduate talents training. This is a systematic project under the guidance of scientific educational idea. The whole training mode includes the goal of personnel training, specifications, educational idea, but also includes undergraduate school guiding ideology, educational theory foundation and talent training ways which an be said as talent building project based on the curriculum system and teaching content. To successfully complete this great project, we must establish a talent training system with the core of quality control and teaching management, and constantly improve own evaluation and social feedback-based personnel training evaluation mechanism. It is of great significance to construct an applied undergraduate training mode in contemporary society. It can make the goal of cultivating undergraduates in colleges and universities more clear, so that the school can handle the relationship of discipline and practice, the training objectives and social needs, schools and enterprises when establishing applied undergraduate majors, and provide scientific guidance for training courses and teaching designs, which can promote the quality of China's education and teaching reform in a certain degree. Moreover, according to the current situation of the development of universities in China, the vast majority of universities already have the basic conditions for constructing the applied undergraduate training mode, including good teacher conditions and the deepening research of applied subjects. Therefore, the innovation and construction of applied undergraduate training mode in universities are feasible.

\subsection{Innovation and Construction Strategies of Applied Undergraduate Training Mode 4.2.1 Focusing on the Training of Professional Ability and Scientific Adjustment of Teaching Content and Curriculum System}

In order to achieve the goal of applied undergraduate training, professional ability must be focused to achieve effective connection of teaching and practice, to deal with the relationship between 
knowledge education and ability training. In the aspect of teaching content and curriculum system, traditional concept should be changed of to make appropriate adjustments of curriculum system and teaching content. On the one hand, comprehensive knowledge of the subject should be included in teaching content, breaking the barriers of discipline. The ability of students to apply their knowledge should be focused according to actual situation, and independent learning and practice opportunities should be offered to students. On the other hand, in the curriculum system, extended courses, practical courses and professional courses should be allocated rationally. The core of professional ability training should be highlighted, not only reflecting professional characteristics, but paying attention to the development of student personality.

\subsubsection{Promoting Teaching Methods and Modes Reform}

In the aspect of teaching mode, traditional teaching model should be changed from teaching oriented to learning oriented, making students play a main part in learning process, encouraging students to actively identify problems and solve problems, so as to develop their ability of handling practical problems. In the aspect of teaching method, research and opening teaching method should be introduced, and the combination of classroom teaching and extracurricular practice can cultivate the ability of applying knowledge. At the same time, the stimulation of students' researching interests should be focused, so as to lay the foundation for their future.

\subsubsection{Improving the Scientificity of Professional Structure according to the Social Development Requirements}

The major universities should follow the pace of times, actively carry out social research, comprehensively analyze the characteristics of social change, seize the essence of these changes, and clear out the relationship between the cultivation of personnel and social development, so as to adjust profession structure, and provide a truly valuable applied talent for social development. At the same time, the school should also improve the professional setting mechanism to build an open professional setting mechanism which can break the shackles of traditional professional settings, and change the drawbacks of ignoring the future development of students in traditional teaching. For the majors that have already been unable to adapt to social development, they should be eliminated in time. In addition, new trend of social development should be considered to integrate original majors and new ones, which can make them better adapt to the needs of today's development, but also not lost the original professional features.

\subsubsection{Changing Teaching Ideas and Establishing the Training Objective of Applied Talents}

School should innovate the concept of personnel training, adhere to "application" as the guide, combine theoretical teaching with practical teaching, fully developing students' practical innovate ability, self-exploration ability and cooperative learning ability, which can ultimately cultivate talents who can solve practical problems. At the same time, school should make the purpose of applied talents to all aspects, running through the curriculum objectives, training objectives and many other aspects. Personnel training objectives must be set up feasibly, personality differences of students should be respected, every student should has clear career orientation, and make corresponding training plan according to students' future development.

\section{Conclusion}

In short, in recent years, although Chinese universities have made some achievements in applied undergraduates training, due to we have always focused on the cultivation of academic undergraduate students, applied undergraduate education in China's started very late and practice time is also relatively short. Therefore, people' understand of this form of education is not enough, and there are some areas of talent training should be improved, including professional settings, teaching content, curriculum system and other aspects. Chinese universities should adhere to the concept of innovation, and actively improve the problems of applied undergraduate training mode, so as to provide more talents for society. 


\section{Acknowledgments}

Found Project: Important Teaching Reform Item in Chongqing: Research and Practice about "Five Pairs Program" Training Mode of College Applied Talents, (No.161006)

\section{References}

[1]. Jiao Jian. Research of Applied Talents Training Mode---Taking the Business Administration Major as an example [D]. Shanxi Finance and Economics University, 2013.

[2]. Niu Dawei. Innovation and Practice of Applied Undergraduate Talent Training Mode [J]. Experiment Science and Technology, 2012,10(2):153-154.

[3]. Wang Shiqing. Several Thinking about Innovate Applied Undergraduate Training Mode [J]. Chinese University Teaching, 2013,(6):20-23. 